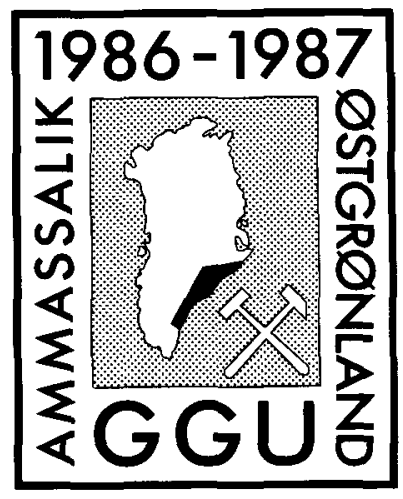

\title{
The Niflheim thrust: a tectonic contact between granulite and amphibolite facies gneisses, South-East Greenland
}

\author{
J. C. Escher and R. P. Hall
}

The Niflheim thrust forms part of the northern boundary zone of the Proterozoic mobile belt of the Ammassalik region and defines the southernmost extent of granulite facies gneisses north-west of Sermilik. The thrust sharply separates grey amphibolite facies gneisses (footwall) from a thick and extensive unit of brown granulite facies gneisses, suggesting considerable lateral as well as vertical transport of the brown gneisses. Above the contact, the brown gneisses have only been weakly affected by deformation, whilst below the contact intensely folded and sheared grey gneisses indicate strong deformation of the upper part of the footwall sequence during thrusting. Asymmetry of folds below the contact and the E-W trending, gently north dipping thrust contact indicate a sinistral transpressional sense of movement with an up-to-the-south main component of transport. Three undeformed, discordant basic Proterozoic dykes in the grey gneisses of the footwall are truncated by the thrust and the thrust plane has been gently folded during a late stage of the regional Proterozoic deformation.

Contrasts between high-grade mineralogy of Proterozoic dykes in the northern part of the Ammassalik region and lower grade, high crustal level dykes of the grey gneiss terrain in the south are related to the regional thrusting from the north.

\section{Introduction}

The northern boundary of the Proterozoic mobile belt of the Ammassalik region, South-East Greenland is an up to 100 kilometres wide $\mathrm{E}-\mathrm{W}$ trending transition zone between predominantly brown granulite facies gneisses to the north and grey amphibolite facies gneisses to the south (Dawes et al., this volume - Northern boundary). This boundary zone comprises numerous irregular anastomosing networks of retrogressed grey gneiss and shear and thrust zones associated with amphibolite facies retrogression. The dislocation zones separate intercalations of brown gneiss from retrogressed grey gneiss and occur on all scales and in all proportions. The shear and thrust zones are generally E-W trending, parallel to the boundary zone, and northwards dipping, implying a southwards sense of displacement of brown high-grade gneisses over grey lower-grade gneisses.

During the few days of fieldwork available for ground investigations a major thrust was studied in northern Niflheim, north-west of Sermilik (see Dawes et al., this volume - Northern boundary, fig. 3).

\section{The Niftheim thrust}

The Niflheim thrust forms a sharp tectonic contact with a footwall of grey gneisses and a hanging wall of brown gneisses (fig. 1). It is situated near the southern limit of the northern boundary zone of the Proterozoic mobile belt. The feature was observed initially from the air by J. S. Myers in 1978 and it came to form the western part of the northern Nagssugtoqidian boundary line of Bridgwater \& Myers (1979, fig. 1), Myers et al. (1979, fig. 28) and Myers (1984, fig. 8; 1987, fig. 2), see Dawes et al. (this volume - Northern boundary).

The Niflheim thrust trends E-W and dips gently $\left(10^{\circ}-\right.$ $50^{\circ}$ ) to the north with a traceable length of around ten kilometres. To the east as well as to the west, the thrust extends beneath the Inland Ice. Below the thrust contact, an approximately $80 \mathrm{~m}$ thick zone consists of strongly deformed grey gneisses (fig. 2). The deformation of the zone is clearly related to the formation of the thrust. Above the thrust contact, the brown gneisses are only weakly deformed up to a distance of about $20 \mathrm{~m}$. Further away from there, the gneisses are unmodified. The thrust is well exposed through a series of low southfacing cliffs which extend towards the Inland Ice.

The approximately $80 \mathrm{~m}$ thick zone of intense ductile 
Fig. 1. Major thrust with sharp contact between brown granulite facies gneisses (hanging wall) overlying grey amphibolite facies gneisses. Deformed remnants of truncated basic dykes (d) occur below the thrust contact. To the lower right, an approximately 30 $m$ thick basic dyke (D) is truncated. Niflheim region north of Sermilik. Height of section about $900 \mathrm{~m}$.

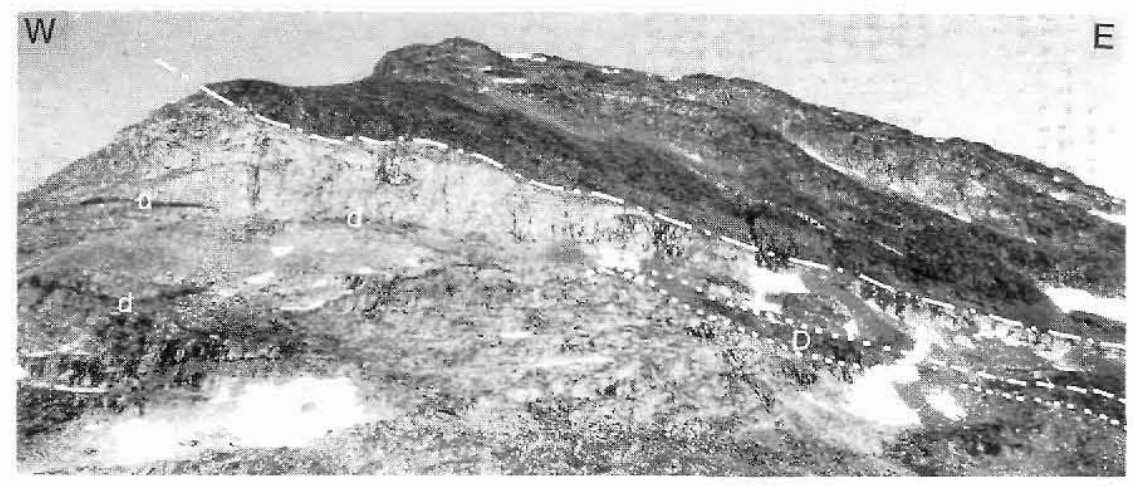

deformation comprises ptygmatic folds and rotated tectonic enclaves of highly folded gneiss, bounded by sheared margins (fig. 2). Abundant shear and dislocation planes occur on all scales, and the foliation and gneissic banding in the grey gneisses clearly represent a new fabric, formed during the thrust movements. The lowermost dislocation plane, at the base of the cliff and visible in fig. 2, separates intensely deformed gneisses from weakly deformed gneisses below.

The sense of movement on the thrust is sinistral transpressional with an up-to-the-south main component of transport. Sinistral strike slip is suggested by the asymmetry of folds in the tectonic enclaves of the shear zone. Similar structures have been recognised in many of the major Laxfordian shear zones of North-West Scotland (Coward \& Park, 1987).

The brown granulite facies gneisses of the hanging wall immediately above the thrust are trondhjemitic in composition with around 10 modal \% ferromagnesian minerals (orthopyroxene, clinopyroxene and actinolite). The rocks are usually fine grained $(0.2 \mathrm{~mm})$ and have a granoblastic texture with large elongate, ribbontextured quartz. About $20 \mathrm{~m}$ above the contact, these rocks grade rapidly into unmodified normal brown gneisses which are nebulitic, slightly more mafic (ferromagnesian minerals 10-20 modal \%), medium grained (c. $1 \mathrm{~mm}$ ), greasy brown-weathering, granoblastic quartzo-feldspathic, and hornblende-, orthopyroxeneand garnet-bearing. The amphiboles and pyroxenes clearly co-exist in a hornblende-granulite facies equilibrium assemblage rather than forming replacement textures.

Many of the grey gneisses of the footwall directly below the thrust are tonalitic-trondhjemitic in composition with up to 25 modal \% hornblende, biotite, chlorite and epidote. These rocks are medium grained (c. $1 \mathrm{~mm}$ ) with a strongly foliated, granoblastic texture. Plagioclase is severely saussuritised. The gneisses contain coarse (1-2 mm) ribbon-textured quartz and plagioclase. Small $(0.1-0.5 \mathrm{~mm})$ euhedral actinolitic amphibole and biotite form together c. 10 modal \%. Highly altered remnants of pyroxene and garnet are rare.

Fig. 2. Ptygmatic folds and rotated enclaves of grey banded gneisses bounded by sheared margins beneath fine-grained granulite facies gneiss (dark grey). Remnants of truncated basic dykes (d) at the bottom. Height of section about $200 \mathrm{~m}$.

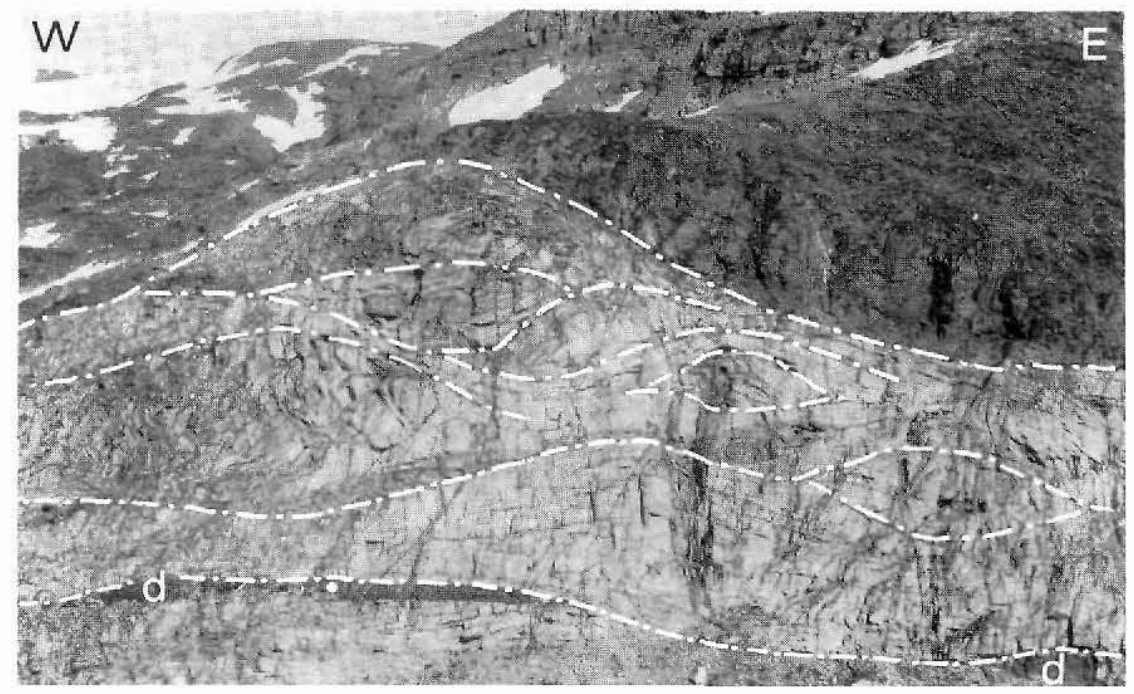


The age of the thrust is constrained by the fact that three undeformed discordant Proterozoic basic dykes are truncated (described later), and that the thrust plane has been gently folded during a late stage of the Proterozoic deformation.

The thrust defines the southernmost extent of major occurences of granulite facies gneisses north of Sermilik (Dawes et al., this volume - Northern boundary, fig. 3). Patches of partially retrogressed, pale-brown weathering granulite facies gneiss do, however, locally occur within the grey gncisses south of the thrust. These patches have diffuse non-tectonic contacts with the grey gneisses. The pale-brown, as well as the grey gneisses, are cut by discordant basic dykes, which, as mentioned earlier, have been truncated by the thrust. These relations indicate that the pale-brown gneisses are older than the thrust and that there is no relation between the pale-brown gneisses (autochthonous) and the brown gneisses from above the thrust. Although the grey gneisses locally show evidence of having been derived from retrogressed granulite facies gneisses, the general field impression is that the bulk of the grey gneisses south of the thrust has never been at granulite facies grade.

\section{Basic dykes}

Three garnet- and metamorphic pyroxene-bearing metadolerite dykes, each about $30 \mathrm{~m}$ thick, strike eastsouth-eastwards from the Niflheim thrust for several kilometres in the grey gneiss terrain. Although these dykes comprise high-grade metamorphic mineral assemblages ranging from garnet-amphibolite to pyroxene-amphibolite (fig. 3), they are virtually undeformed and discordant to the gneisses. They are associated with

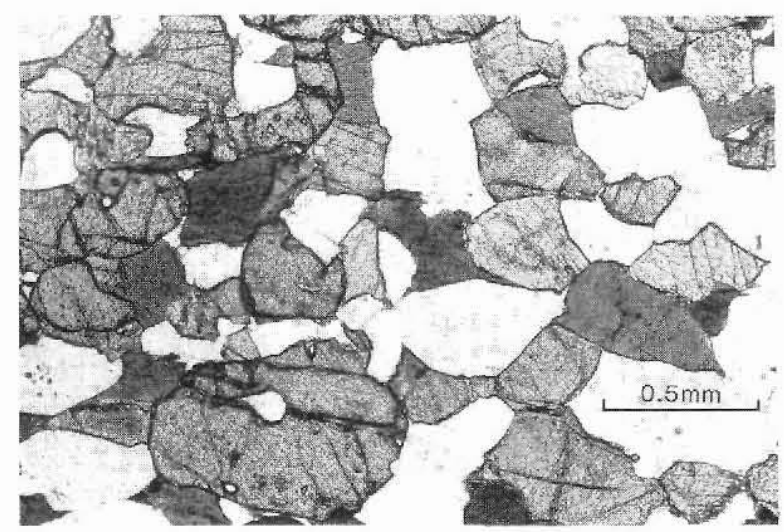

Fig. 3. Granoblastic garnet-clinopyroxene-hornblende-plagioclase metadolerite. From central part of a $30 \mathrm{~m}$ dykc, collected about $1 \mathrm{~km}$ south-east of the Niflheim thrust. Plane polarised light.

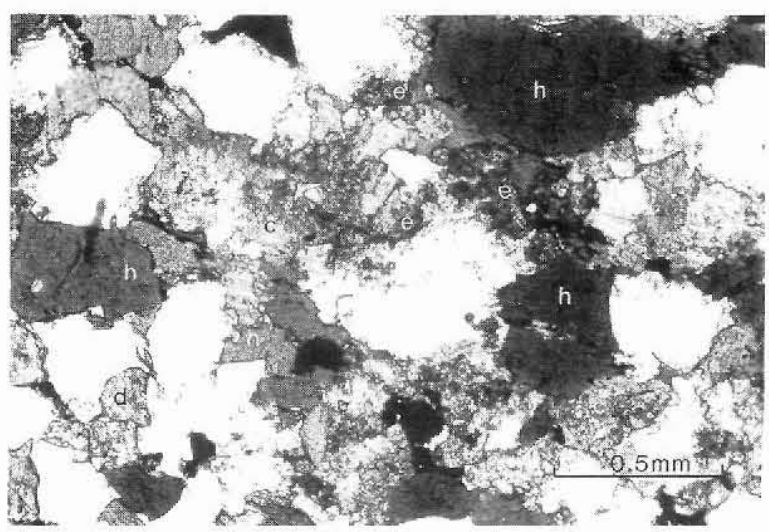

Fig. 4. Altered epidote-chlorite-hornblende-plagioclasesphene metadolerite remnant from within the thrust zone. $d=$ diopside, $\mathrm{h}=$ hornblende, $\mathrm{e}=$ epidote, $\mathrm{c}=$ chlorite. Plane polarised light.

abundant decimetre to metre thick satellite dykes, a common feature of the Charcot Fjelde dykes which occur throughout the northern Ammassalik region (Myers et al., 1979; Dawes et al., this volume - Northern boundary)

Towards the Niflheim thrust, the three dykes gradually become thin, boudinaged and foliated in the vicinity of the thrust. They are truncated by the basal thrust plane (fig. 2) and were not observed in the brown gneisses above the thrust zone. Similar dykes are, however, common in granulite facies gneisses elsewhere in the northern region. The boudinaged dyke remnants in the thrust zone comprise foliated, fine-grained, epidote amphibolite in which epidote and amphibole replace pyroxene (fig. 4).

\section{Discussion and regional correlation}

When compared with the other shear and thrust zones of the northern boundary zone, the Niflheim thrust shows certain similarities, as well as a number of differences. Similarities include E-W trend, northerly dip, and up-to-the-south thrust movements, indicating that the thrust belongs to the shear and thrust system of the boundary zone. The main differences are that:

(a) the thrust forms a sharp metamorphic facies contact, in contrast with the generally diffuse contact zones of the other shear and thrust zones;

(b) the thrust did not cause retrogression of the overlying granulite facies gneisses, whereas most of the other shear and thrust zones are associated with well developed retrogression zones.

(c) the thrust forms a boundary between a large area of unmodified brown gneisses to the north and the grey 
gneisses of the mobile belt to the south, whilst most of the other shear and thrust structures separate intercalations of mixed facies gneisses.

(d) the thrust has not been intruded by Proterozoic dykes, but rather truncates some of them. This is basically different from many of the other shear and thrust zones, which contain subconcordant basic dykes, although a number of these zones have been reactivated, deforming and truncating dykes (Dawes et al., this volume - Northern boundary).

These differences suggest a contrast in tectono-metamorphic style (a, b), considerable lateral as well as vertical transport of the overlying brown gneisses (c), and indicate that the Niflheim thrust was formed during a late stage of the Proterozoic deformation when a number of the shear and thrust zones were reactivated (d).

The granoblastic textures and high-grade mineralogy of $\mathrm{E}-\mathrm{W}$ trending basic dykes (two pyroxenes + garnet + plagioclase) in both the boundary zone and in the granulite facies terrain further to the north, are typical of some basic dykes in the Nagssugtoqidian mobile belt of southern West Greenland and the Scourie dykes of North-West Scotland (Glassley \& Sørensen, 1980; Tarney \& Weaver, 1987). In this respect they differ from Proterozoic dykes of West Greenland (the MD dykes), which contain complex igneous pyroxene assemblages indicative of low pressure, high-level dyke emplacement. The Scourie dykes are estimated to have been intruded under amphibolite facies conditions, with tem- peratures of around $600^{\circ} \mathrm{C}$ and at a depth of 15 to $20 \mathrm{~km}$ (Tarney \& Weaver, 1987). The boundary zone and the granulite facies terrain further to the north were probably at comparable high pressure and high temperature conditions during and after the emplacement of the dykes. In contrast, in the Umîvik area $\left(64^{\circ} 15^{\prime} \mathrm{N}\right.$, near the southern margin of the mobile belt) E-W trending basic dykes retain a complex igneous mineralogy akin to that of the high-level MD dykes (Hall et al., this volume - Basic dykes). The contrast between the deep crustal mineralogy of the dykes north of the Niflheim thrust and that of the high level dykes in the Umîvik area is, of course, due to the regional southward thrusting of deeplevel granulite facies gneisses from the northern part of the Ammassalik region over amphibolite facies gneisses in the south.

Ductile deformation structures, similar to those in the Niflheim thrust zone (fig. 2), characterise a number of the Laxfordian shear zones of North-West Scotland (e.g. Coward \& Park, 1987). The occurrence of these structures, and the similarity between the deep crustal emplacement of the Scourie dykes and some of the E-W dykes in the northern part of the Ammassalik region, suggest that the Lewisian gneiss complex of North-West Scotland correlates more closely with the gneiss complex of the northern boundary zone than with the unmodified Archaean gneiss complex with highlevel basic dykes of the Tingmiarmiut-Umîvik region $\left(62^{\circ} 30^{\prime}-64^{\circ} 15^{\prime} \mathrm{N}\right)$, as proposed by Bridgwater et al. (1973c) and Korstgård et al. (1987). 